Article

\title{
Enhanced stability of highly-dispersed copper catalyst supported by hierarchically porous carbon for long term selective hydrogenation
}

\author{
Nian Hu a,†, Xiao-Yun Li b,†, Si-Ming Liu a, Zhao Wang a,*, Xiao-Ke He a, Yue-Xin Hou a, \\ Yu-Xiang Wang a, Zhao Deng a, Li-Hua Chen a,\#, Bao-Lian Su a,c,d,\$ \\ a Laboratory of Living Materials, the State Key Laboratory of Advanced Technology for Material Synthesis and Processing, Wuhan University of \\ Technology, Wuhan 430070, Hubei, China \\ b State Key Laboratory of Silicate Materials for Architectures, Wuhan University of Technology, Wuhan 430070, Hubei, China \\ c Laboratory of Inorganic Materials Chemistry (CMI), University of Namur, B-5000 Namur, Belgium \\ d Clare Hall, University of Cambridge, Cambridge CB3 9AL,
}

\section{A R T I C L E I N F O}

\section{Article history:}

Received 26 November 2019

Accepted 18 December 2019

Published 5 July 2020

\section{Keywords:}

Hierarchically porous structure

Catalyst

$\mathrm{Cu} / \mathrm{C}$

Selective hydrogenation

Metal organic frameworks

\begin{abstract}
A B S T R A C T
Copper based catalysts have high potential for the substituent of noble-metal based catalysts as their high selectivity and moderate activity for selective hydrogenation reaction; however, achieving further high catalytic stability is very difficult. In this work, the carbonization process of $\mathrm{Cu}$-based organic frameworks was explored for the synthesis of highly-dispersed $\mathrm{Cu}$ supported by hierarchically porous carbon with high catalytic performance for selective hydrogenation of 1,3-butadiene. The porous hierarchy of carbon support and the dispersion of copper nanoparticles can be precisely tuned by controlling the carbonization process. The resultant catalyst carbonized at $600{ }^{\circ} \mathrm{C}$ exhibits a rather low reaction temperature at $75{ }^{\circ} \mathrm{C}$ for $100 \%$ butadiene conversion with $100 \%$ selectivity to butenes, due to its reasonable porous hierarchy and highly-dispersed copper sites. More importantly, unprecedentedly stability of the corresponding $\mathrm{Cu}$ catalyst was firstly observed for selective 1,3-butadiene hydrogenation, with both $100 \%$ butadiene conversion and $100 \%$ butenes selectivity over $120 \mathrm{~h}$ of reaction at $75^{\circ} \mathrm{C}$. This study verifies that a simply control the carbonization process of metal organic frameworks can be an effective way to obtain Cu-based catalysts with superior catalytic performance for selective hydrogenation reaction.
\end{abstract}

(C) 2020, Dalian Institute of Chemical Physics, Chinese Academy of Sciences. Published by Elsevier B.V. All rights reserved.

\section{Introduction}

Unsaturated hydrocarbons, especially alkenes, have been wildly used as raw materials in current industry for the synthesis of rubber, plastics and organic chemical materials by polymerization reaction [1]. However, various impurities are

\footnotetext{
* Corresponding author. Tel: +86-13628664510; E-mail: zhao.wang@whut.edu.cn

\# Corresponding author. Tel: +86-13628644340; E-mail: chenlihua@whut.edu.cn

\$Corresponding author. Tel: +86-13644968782; E-mail: bao-lian.su@unamur.be

${ }^{\dagger}$ The two authors contributed equally to this work.

This work was supported by Program for Changjiang Scholars and Innovative Research Team in University (IRT_15R52) of the Chinese Ministry of Education. B. L. Su acknowledges the Chinese Ministry of Education for a "Changjiang Chaire Professor" position and a Clare Hall Life Membership, University of Cambridge. L. H. Chen acknowledges Hubei Provincial Department of Education for the "Chutian Scholar" program. This work was also financially supported by the National Natural Science Foundation of China (21671155, U1663225, 21902122, 21805216), Major programs of technical innovation in Hubei (2018AAA012), Hubei Provincial Natural Science Foundation (2018CFA054), Postdoctoral Science Foundation of China (2019M652723), and the Fundamental Research Funds for the Central Universities (2019IVA116).
}

DOI: 10.1016/S1872-2067(20)63570-7 | http://www.sciencedirect.com/science/journal/18722067 | Chin. J. Catal., Vol. 41, No. 7, July 2020 
usually contained in the unsaturated hydrocarbons, which are mainly produced by crude oil cracking, such as acetylene impurities (1000-10000 ppm) in ethylene stream [2], butyne and butadiene (3000-8000 ppm) in butenes stream [3]. As well known, the impurities of alkynes and alkadienes can easily poison the initiators employed for the polymerization of alkenes [4]. For instance, the 2-butyne impurity in butenes feed can easily react with the $\mathrm{Cp}_{2}{ }_{2} \mathrm{ScCH}_{3}\left[\mathrm{Cp}^{*}=\left(\eta^{5}-\mathrm{C}_{5} \mathrm{Me}_{5}\right)\right]$ initiator, forming $\mathrm{Cp}_{2}{ }_{2} \mathrm{Sc}\left(\mathrm{CH}_{3}\right) \mathrm{CH}=\mathrm{CH}\left(\mathrm{CH}_{3}\right)_{2}$, which results in a termination of the butene polymerization reaction at concentration as low as $10 \mathrm{ppm}$ [5]. Thus, these impurities have to be eliminated, usually, by selective hydrogenation that can transform the impurities into the corresponding alkenes raw materials, resulting in a high carbon utilization. Since the reaction barrier value of alkenes hydrogenated to alkanes is relatively low [6], and alkenes are easily further hydrogenated to alkanes, thus high selectivity to semi-hydrogenation is one of the most important factors for an ideal catalyst $[7,8]$. Currently, noble metals (e.g., Pd, Pt, Au, etc.) are widely used as heterogeneous catalysts due to their high catalytic performance for hydrogenation reactions $[9,10]$. However, noble metallic catalysts normally have low selectivity to alkenes (70\%-85\%) during the catalytic selective hydrogenation reaction because of their strong hydrogen activation [10-12]. In order to increase the selectivity to alkenes, nowadays, one of the most wildly used method is to modify the surficial property (i.e., electro density, the distribution of noble metal atom and so on) by introducing a second non-noble metal assistant, and forming noble/non-noble bimetallic catalysts, such as Pd-Ni[9], Pd-Cu [13-15], Pd-Co [16,17], Pd-Zn [18,19], Pt-Cu [20-23] and so on. Specifically, the Pt-Cu alloys supported on $\mathrm{Al}_{2} \mathrm{O}_{3}$ synthesized by Lucci et al. [21] have shown 99\% butenes selectivity at full conversion temperature $\left(T_{100 \%}\right)$ in selective hydrogenation of butadiene reaction. However, the scarcity and the high cost (above 10,000 dollars per kilogram) of noble metals limit their long-term development in the field of catalysis[7]. Non-noble metals are nearly 3,000 times cheaper than noble metals, and they also have been predicted by the theoretical calculation of Norskov's group [24] that they show high potential for the substituent of noble-metal based catalysts in the reaction of selective hydrogenation [25], due to their inferior adsorption of alkynes and alkadienes.

Supported $\mathrm{Cu}$ catalysts show rather high potential for this type of reaction, due to their high selectivity to alkenes and moderate reaction condition. Thus, plenty of works have been focused on the exploration of $\mathrm{Cu}$-based catalysts, including the synthesis method, the modification of catalytic performance and so on [24]. As for synthetic strategies, the wildly used methods are ion exchange [26], wet impregnation [27], and deposition precipitation $[7,8,10]$ and so on, which are mainly belonged to aqueous precursor solutions methods. For example, Wang have prepared $\mathrm{Cu} / \mathrm{TiO}_{2}$ catalysts by deposition-precipitation with urea (DPu), and found that DPu time has a great effect on the structure of $\mathrm{TiO}_{2}$ supported $\mathrm{Cu}$ species, e.g., $\mathrm{Cu}_{2}(\mathrm{OH})_{3} \mathrm{NO}_{3}$ and $\mathrm{CuO}$ for $\mathrm{DPu}$ of 3 and $20 \mathrm{~h}$, and results in a $T_{100 \%}$ at 75 and $90{ }^{\circ} \mathrm{C}$, respectively, under a constant $\mathrm{Cu}$ loading. However, even though supported $\mathrm{Cu}$ has high selectivity with moderate $T_{100 \%}$ temperature, but researchers [8] have found that it deactivates very fast due to a rapid formation of green oil layer on the surface of $\mathrm{Cu}$ surface, e.g., within the first 20 min of reaction for selective ethylene hydrogenation. There is a general agreement about the mechanism of deactivation, that is, the half-hydrogenated intermediate formed by selective hydrogenation can react further with hydrogen to isomerise to form a free radical which can react with more adsorbed butadiene to produce green oil [28]. According to previous studies on metallic catalysts for selective hydrogenation $[5,10,21]$, elevating the transfer efficiency of alkenes by design of porous support could be an attractive path to promote $\mathrm{Cu}$ catalysts stability in selective hydrogenation.

The construction of hierarchically interconnected pores on supports conduce to enhancing catalytic performance by means of the transfer and exchange of substances with extremely high efficiency and minimum energy consumption $[29,30]$ In recent years, sorts of synthesis methods have been explored for the preparation of hierarchically porous materials [31]. As a substance with well-developed porosity and high-density metal content, metal organic frameworks (MOFs) exhibit a potential for using as an ideal matrix to prepare hierarchically porous carbon supported metallic catalysts [32-34]. Hierarchically porous carbon can be self-formed by the aggregation of metal NPs in the process of carbonization of MOFs, which is conducive to mass transfer efficiency [35,36]. Besides that, it has been proved that if metal ions have the reduction potential of $-0.27 \mathrm{~V}$ or higher, the corresponding MOFs after pyrolysis always form metal nanoparticles (NPs) in a protective atmosphere, whereas metal ions with a reduction potential lower than $-0.27 \mathrm{~V}$ form metal oxide NPs [35]. The reduction potentials of $\mathrm{Cu}^{2+}$ is found to be $+0.34 \mathrm{~V}$, indicating that copper ions are able to be reduced to copper under the same pyrolysis condition. Since $\mathrm{Xu}$ and co-workers [32] described porous carbon materials derived from MOF-5 in 2008, the utilization of MOFs as precursor for metal/metal oxide NPs inside porous carbon frameworks (M/MO@C) have attracted a great deal of research interest. Recently, Li et al. [37] have successfully prepared the pyrolysed ZIF-8 supported $\mathrm{Cu}$ catalyst, which was employed as the cathode catalyst for oxygen reduction reaction. Due to their high surface area and large pore volume, hierarchically porous carbon supported non-noble metallic catalysts derived from MOFs have been widely explored in electrochemical catalysis [37-39], but rarely reported in selective hydrogenation catalysis. Since Pd/Cz-MOF-253 prepared by Huang et al. [40] was first applied as solid-based catalysts for a one-pot stepwise tandem reaction of Knoevenagel condensation and subsequent hydrogenation in 2017, much attention now has gradually paid on the application of MOFs-derived catalysts in heterogeneous catalysis. The recent study has also report [41] that highly dispersed and accessible $\mathrm{Cu} / \mathrm{Cu}_{2} \mathrm{O}$ heterojunctions inside porous organic matrices through pyrolysis of copper-based MOFs (i.e., ZJU-199), demonstrating excellent catalytic properties in liquid-phase hydrogenation of furfural into furfuryl alcohol.

Considering the fact that copper has high selectivity and relative high activity, however the low catalytic stability is the 
critical problem to the application of selective hydrogenation reaction. Herein, copper-based MOF (i.e., HKUST-1) was selected as the matrix for preparation of monometallic $\mathrm{Cu}$ supported on hierarchically porous carbon by one-step in-situ carbonization. The state of $\mathrm{Cu}$ (i.e., particle size, valence state) and the structure of hierarchically porous carbon were explored as a function of carbonization temperature. Besides that, the catalytic activity, selectivity to alkenes and stability of the carbonized HKUST-1 were explored for selective butadiene hydrogenation reaction. After that, the relationship between the particle size of $\mathrm{Cu}$ and the property of supported carbon species and the catalytic performance was mainly discussed. This work could provide a promising method for the synthesis of copper-based catalysts with high catalytic performance.

\section{Experimental}

\subsection{Materials and chemicals}

All reagents and solvents of analytical grade were used as received without further purification. Copper (II) nitrate trihydrate (99\%), anhydrous ethanol (99.5\%) were purchased from Sinopharm Chemistry Reagent Co., Ltd. (Beijing, China). Benzene-1,3,5-tricarboxylic acid (98\%) were obtained from Aladdin Industrial Corporation (Shanghai, China).

\subsection{Synthesis of HKUST-1 matrix}

The hydrothermal synthesis mixture for HKUST-1 was scaled up as described in the literature [42]. In detail, copper

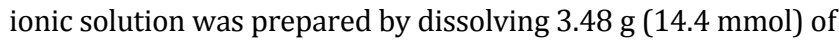
$\mathrm{Cu}\left(\mathrm{NO}_{3}\right)_{2} \cdot 3 \mathrm{H}_{2} \mathrm{O}$ in $48 \mathrm{ml}$ of deionized water in a beaker. Then, $1.68 \mathrm{~g}$ ( $8.0 \mathrm{mmol})$ of $\mathrm{H}_{3} \mathrm{BTC}$ was weighted and dissolved in 48 $\mathrm{ml}$ of anhydrous ethanol. After that, the copper nitrate solution was slowly added to $\mathrm{H}_{3} \mathrm{BTC}$ solution, followed by continuous magnetic stirring for $20 \mathrm{~min}$ at room temperature. Subsequently, the blue turbid liquid was transferred into a teflon-lined autoclave and kept at $120{ }^{\circ} \mathrm{C}$ for several hours. After that, precipitation were collected by filtration and washed thoroughly with $250 \mathrm{ml}$ mixture of ethanol and deionized water $(\% V / V$ of water $=50 \%)$ [43]. The blue product was dried at $120{ }^{\circ} \mathrm{C}$ overnight and stored in sealed vials for further experiments.

\subsection{Preparation of D-HKUST-1-X}

The HKUST-1 matrix was added into different porcelain boats. Various carbonization temperature (i.e., 350, 400, 450, $500,600,700,800,900^{\circ} \mathrm{C}$ ) was selected for obtaining hierarchically porous carbon supported copper catalyst. Detailly, the HKUST-1 matrix was carbonized from room temperature (RT) to the corresponding temperature under an argon flow with a heating rate of $2{ }^{\circ} \mathrm{C} \cdot \mathrm{min}^{-1}$ and then kept at certain temperature for $4 \mathrm{~h}$ in a tubular furnace. Here, the derivatives of HKUST-1 catalysts were marked as D-HKUST-1- $X(X=$ carbonization temperature).

\subsection{Catalytic test}

Selective 1,3-butadiene hydrogenation reaction on D-HKUST-1-X catalysts was carried out in a plug-flow reactor. $100 \mathrm{mg}$ of catalyst was loaded in quartz tube with the internal diameter of $8 \mathrm{~mm}$. Prior to the catalytic test, catalysts were in situ activated under hydrogen $\left(50 \mathrm{ml} \cdot \mathrm{min}^{-1}\right)$ from room temperature (RT) to $350{ }^{\circ} \mathrm{C}$ with a heating rate of $2{ }^{\circ} \mathrm{C} \cdot \mathrm{min}^{-1}$ and then kept at $350{ }^{\circ} \mathrm{C}$ for $2 \mathrm{~h}$. After cooling down to room temperature under hydrogen, a gas mixture, containing $0.3 \% 1$, 3-butadiene, $30 \%$ propene, $20 \%$ hydrogen and balance helium, was introduced into the reactor with a total flow rate of 100 $\mathrm{ml} \cdot \mathrm{min}^{-1}$. To simulate the real condition in industry (i.e., butadiene in an excess of butenes), small amount of butadiene $(0.3 \%)$ in an excess of propene $(30 \%)$ was employed as initial reactant in this laboratorial study [10]. The activities of D-HKUST-1-X catalysts were evaluated from $30{ }^{\circ} \mathrm{C}$ to the temperature at which 1,3-butadiene conversion reaches $100 \%$, with a heating rate of $1{ }^{\circ} \mathrm{C} \cdot \mathrm{min}^{-1}$. After catalytic reaction, the products were analyzed in situ by introducing the outlet gas to a gas chromatograph (GC2030Smart, FID detector) every 15 min, every $15^{\circ} \mathrm{C}$. Through the preliminary experiments [10] , it has been proved that the internal and external diffusion restrictions could be ignored under this catalytic conditions and at low conversion. Moreover, the catalytic stability of D-HKUST-1-X was also analyzed at the temperature, which firstly showed a $100 \%$ butadiene conversion, for $20 \mathrm{~h}$. In addition, a much longer stability time (i.e., $120 \mathrm{~h}$ ) was also selected for verify the high stability of the D-HKUST-1-X. A short view of our strategy is depicted in Scheme 1.

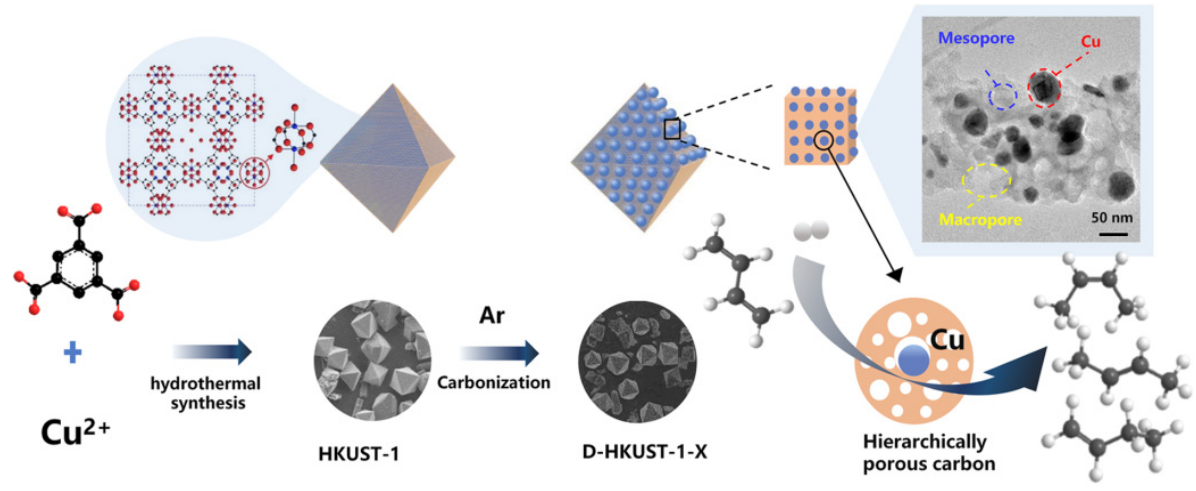

Scheme 1. Illustration of the synthesis of D-HKUST-1-X catalysts for butadiene hydrogenation reaction. 


\subsection{Characterizations}

Scanning electron microscopy (SEM) images were obtained by a JSM $7800 \mathrm{~F}$ instrument operated at $5 \mathrm{kV}$. Transmission electron microscopy (TEM) images were acquired on a JEOL 2100 microscope (Japan) operating at an acceleration voltage of $200 \mathrm{kV}$. X-ray powder diffraction (XRD) patterns were generated by scanning $2 \theta$ with $0.05^{\circ}$ step size and 0.5 s per step on a Rigaku D/Max $2550 \mathrm{~V}$ diffractometer ( $\mathrm{Cu} K_{\alpha}$ radiation, $40 \mathrm{kV}$, $40 \mathrm{~mA}$ ). Thermogravimetric analysis (TGA) was carried out on a TGA-50 thermogravimetric analyzer. Fourier transform infrared (FTIR) measurement was operated at a Varian Excalibur Series 3100 spectrophotometer with the dried KB disk technique. The loading of copper in the D-HKUST-1-X were measured by inductively coupled plasma atomic emission spectrometry (ICP-AES, IRIS Intrepid II XSP). The $\mathrm{N}_{2}$ adsorption-desorption isotherm was measured on Micromeritics Tristar II 3020 system at $-196{ }^{\circ} \mathrm{C}$. The samples were degassed at $120^{\circ} \mathrm{C}$ for $8 \mathrm{~h}$ in quartz tubes before the experiment. The surface area and pore size distribution (PSD) were depended on the Brunauer Emmett-Teller (BET) method and derived from the desorption branch of the isotherm based on the Barett Joyner-Halenda (BJH) model. The Raman spectra were conducted on RENISHAW Raman microscope.

\section{Results and discussion}

\subsection{Characterization of HKUST-1 matrix}

The time of hydrothermal treatment for the synthesis of HKUST-1 was explored and optimized in this work as the experimental condition various from different laboratories. Here, it was found that the particle size of HKUST-1 grew from 10 to $20 \mu \mathrm{m}$ (Fig. S1) with hydrothermal treatment time increasing. Besides that, a volcano distribution can be observed in the aspect of crystallinity (Fig. S2) and porous volume (Table. S1) for the sample synthesized at different times, moreover, with a well-defined octahedral crystal obtained in the condition of hydrothermal treatment at $120{ }^{\circ} \mathrm{C}$ for $18 \mathrm{~h}$. Thus, here this
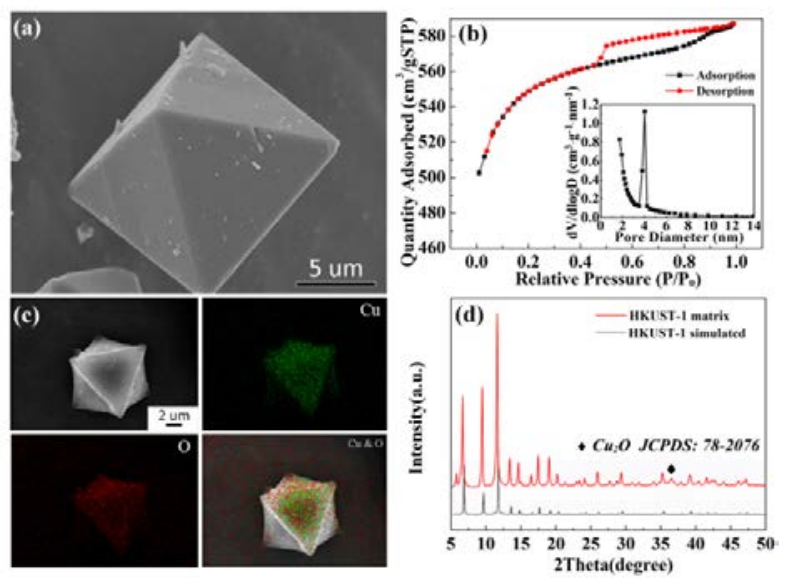

Fig. 1. (a) SEM image of HKUST-1 matrix; (b) $\mathrm{N}_{2}$ adsorption-desorption isotherm curve of HKUST-1 matrix with the inset showing the distribution of the pore sizes; (c) EDX mapping of copper and oxygen; (d) XRD patterns of HKUST-1 matrix. synthesized condition was selected for the further exploration of the HKUST-1 derived carbon supported $\mathrm{Cu}$ catalyst. Furthermore, the specific property of the sample synthesized at $120{ }^{\circ} \mathrm{C}$ for $18 \mathrm{~h}$ is summarized in Fig. 1. In detailed, The HKUST- 1 matrix synthesized at $120^{\circ} \mathrm{C}$ for $18 \mathrm{~h}$ has a crystallite size about $15 \mu \mathrm{m}$ (Fig. 1(a)), high surface area $\left(A_{B E T}\right)$ of 1599 $\mathrm{m}^{2} \cdot \mathrm{g}^{-1}$, large total pore volume $\left(V_{p}\right)$ of $0.91 \mathrm{~cm}^{3} \cdot \mathrm{g}^{-1}$ (Figs. $1(\mathrm{~b})$, and S3, Table S1) and good crystallinity (Fig. 1(d)). Moreover, as shown in the energy-dispersive X-ray spectroscopy (EDX) mapping (Fig. 1(c)) that $\mathrm{Cu}$ ions have uniformly dispersion in the octahedral matrix, indicating the high potential of HKUST-1 matrix for the preparation of $\mathrm{Cu}$-based catalyst. By the way, a few amounts of $\mathrm{Cu}_{2} \mathrm{O}$ was also detected by XRD in the as-prepared HKUST-1, similar phase was also observed in previous study [44].

\subsection{Characterization of D-HKUST-1-X}

The selection of carbonization temperature was based on the weight loss of as-prepared HKUST-1 during thermogravimetric analyzer analyzation, thus 350,400, 450, 500, 600, 700, $800,900^{\circ} \mathrm{C}$ ) were used in this study (Fig. S4). After carbonization, the color of HKUST-1 matrix changed from blue to black as a result from the decomposition of the organic linkers in HKUST-1 (Fig. S5). According to the scanning electron microscope (Fig. 2), it can be found that the original octahedron

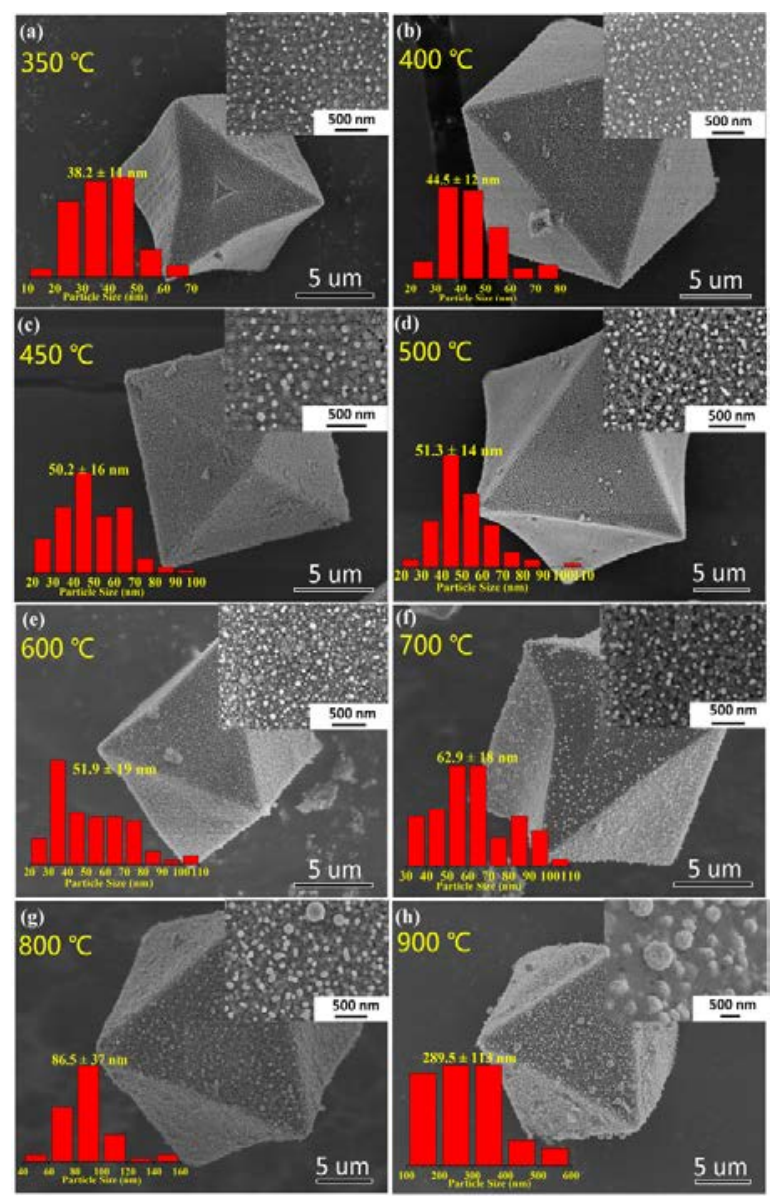

Fig. 2. SEM images of D-HKUST-1-X with the inset showing their high-resolution SEM images and size distributions of metal particles. 

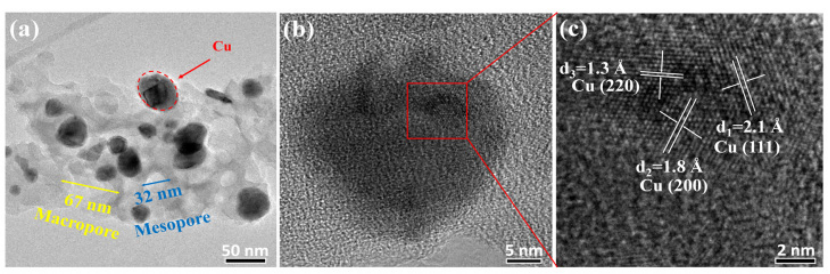

Fig. 3. (a) TEM images of the D-HKUST-1-450; Low- (b) and high-magnified (c) TEM images of the $\mathrm{Cu}$ nanoparticle in D-HKUST-1-450.

structure of HKUST-1 was maintained very well after carbonization, no matter the carbonization temperature is. And plenty of metallic $\mathrm{Cu}$ particles (i.e., bright dots) could be clearly observed in the insert graphs in Fig. 2 with an increased magnification. The distribution of $\mathrm{Cu}$ particle size was summarized by counting more than 200 isolated particles and presented in Fig. 2. It shows that the average $\mathrm{Cu}$ particle size increases gradually from 38 to 45, 50, 51, 52, 63, 87, $290 \mathrm{~nm}$ with the carbonization temperature increasing from 350 to $400,450,500,600,700$, $800,900{ }^{\circ} \mathrm{C}$, respectively. Besides that, it also shows that most of $\mathrm{Cu}$ nanoparticles (NPs) were well encapsulated in carbon substrates at low carbonization temperature, and they were gradually exposed on the surface of carbon at high carbonization temperature. Meanwhile, the porous hierarchy structure gradually appeared in the carbonized HKUST-1 with an increase of carbonization temperature (inset Fig. 2),

Even though SEM results indicates that the average particle sizes of supported $\mathrm{Cu}$ are large in the carbonized HKUST-1 samples, e.g., $\sim 50 \mathrm{~nm}$ in the sample carbonized at $450{ }^{\circ} \mathrm{C}$, but the question about whether small $\mathrm{Cu}$ NPs also existed in the carbon matrix has also to be answered. Thus, HKUST-1 carbonized at $450{ }^{\circ} \mathrm{C}$ (D-HKUST-1-450) was selected for further transmission electron microscopy characterization (Fig. 3). As seen from Fig. 3, most particles with size around $50 \mathrm{~nm}$ are characterized and they seem agree with the average size summarized from SEM (Fig. 2(c)). However, plenty of small particles, with size smaller than $20 \mathrm{~nm}$, were also imaged and embedded in the carbon layer. As shown in the high-resolution TEM images (Fig. 3(b), (c)), the lattice distance is determined to be 2.1, $1.81 .3 \AA$, which are corresponding to the $\mathrm{Cu}(111)$, $\mathrm{Cu}(200)$ and $\mathrm{Cu}(220)$, respectively. It indicates that most of $\mathrm{Cu}^{2+}$ in the structure of HKUST-1 have been successfully reduced to $\mathrm{Cu}$. As a result, it allows to conclude that the particle size of Cu obtained by carbonization of HKUST-1 is not uniform, with large particle $(\sim 50 \mathrm{~nm})$ and small ones $(<20 \mathrm{~nm})$, simultaneously. Besides that, based on TEM, carbon support was found to contain a type of hierarchically meso-macroporous structures. This type of hierarchically porous structure might be generated by the agglomeration of $\mathrm{Cu}$ NPs during carbonization of HKUST-1, and it was also observed in previous study related to the hierarchically flower-like $\mathrm{N}$-doped porous carbon materials [45].

Besides that, after carbonization at varies temperatures, the porous hierarchy and the $\mathrm{Cu}$ loading in HKUST-1 derived carbon supported $\mathrm{Cu}$ samples were further analyzed by $\mathrm{N}_{2}$ adsorption-desorption and inductively coupled plasma optical emission spectrometry, respectively. In Fig. 4, the isotherm curves exhibit a clear hysteresis loop in the relative pressure range $0.5 \leq P / P_{0} \leq 1.0$, and it indicates that the presence of extensive mesoporous structures in all D-HKUST-1-X samples. It has to be mentioned that, as for the sample carbonized at temperature lower than $500{ }^{\circ} \mathrm{C}$, the isotherm curves of adsorption and desorption cannot form a closed loop, which forces the $\mathrm{N}_{2}$ adsorption/desorption test stop and no data can be obtained. The unclosed loop $\mathrm{N}_{2}$ adsorption/desorption curve is usually caused by the exist of non-rigid porous structures or to the irreversible adsorption of molecules in open pores of approximately the same size as the molecule [46]. Here, it may suggest that there are any undecomposed organic parts in the structure of these samples, and further evidence related to the $\mathrm{C}=\mathrm{C}, \mathrm{C}-\mathrm{O}$, $\mathrm{C}-\mathrm{H}$ band were detected by fourier transform infrared (FTIR) analysis (Fig. S6). Moreover, the detailed information is summarized in Table 1 , including specific surface area $\left(A_{B E T}\right)$, total pore volume $\left(V_{p}\right)$, pore dimeter $\left(D_{p}\right)$ and $\mathrm{Cu}$ loading $\left(\omega_{C u}\right)$. As it is shown in Table $1, A_{B E T}$ and $V_{p}$ exhibit a volcano variation with the increase of carbonization temperature. Compared with other samples, the one carbonized at $600{ }^{\circ} \mathrm{C}$ (i.e., D-HKUST-1-600) exhibited a well-structured porous hierarchy, with high BET surface area of $241 \mathrm{~m}^{2} \cdot \mathrm{g}^{-1}$, large pore volume of
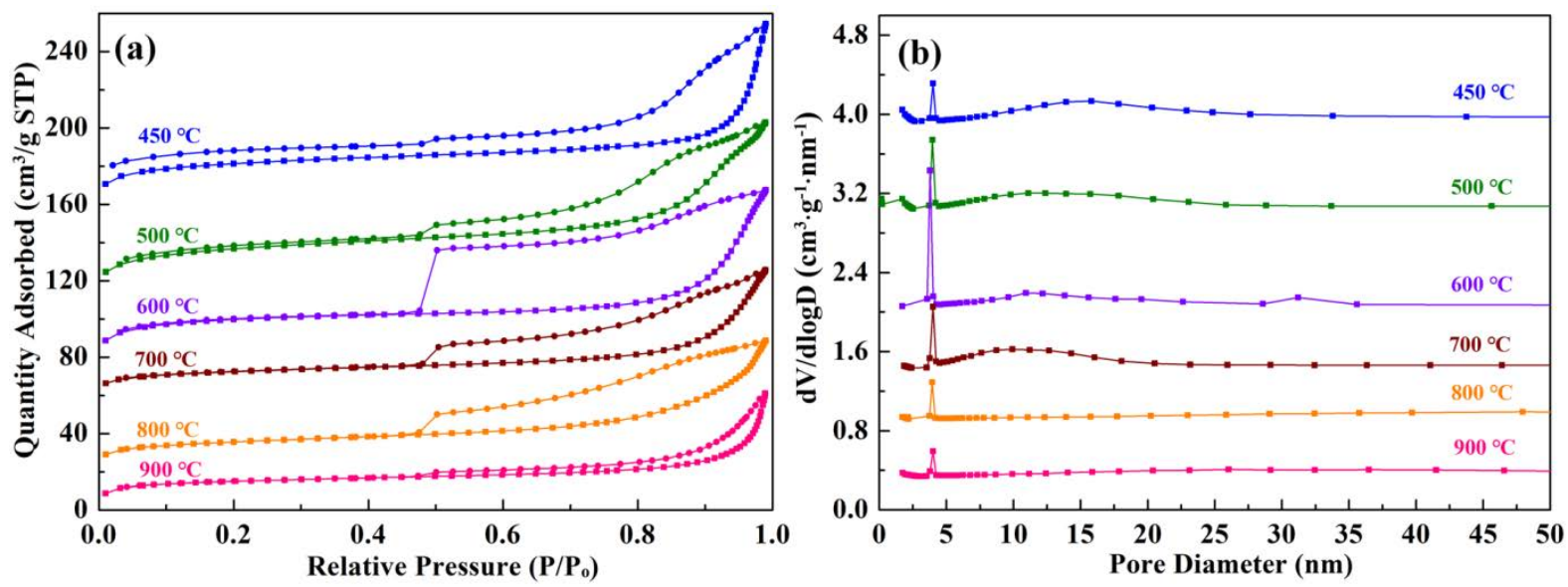

Fig. 4. $\mathrm{N}_{2}$ adsorption-desorption isotherm curves (a) of D-HKUST-1-X, with the corresponding pore sizes distribution (b). 
Table 1

Textural parameters of the D-HKUST-1-X.

\begin{tabular}{lcccc}
\hline Sample & $\begin{array}{c}A_{B E T^{\mathrm{a}}} \\
\left(\mathrm{m}^{2} \cdot \mathrm{g}^{-1}\right)\end{array}$ & $\begin{array}{c}V_{p}^{\mathrm{b}} \\
\left(\mathrm{cm}^{3} \cdot \mathrm{g}^{-1}\right)\end{array}$ & $D_{p}{ }^{\mathrm{c}}(\mathrm{nm})$ & $\begin{array}{c}\omega_{\mathrm{cu}}{ }^{\mathrm{d}} \\
(\mathrm{wt} \%)\end{array}$ \\
\hline D-HKUST-1-450 & 106 & 0.17 & $1.7,3.8,15.0$ & 49.77 \\
D-HKUST-1-500 & 180 & 0.19 & $1.7,3.8,11.8$ & 49.95 \\
D-HKUST-1-600 & 241 & 0.23 & $3.8,11.2,31.5$ & 51.72 \\
D-HKUST-1-700 & 194 & 0.20 & $3.8,10.0$ & 52.37 \\
D-HKUST-1-800 & 180 & 0.18 & 3.8 & 48.65 \\
D-HKUST-1-900 & 143 & 0.15 & 3.8 & 48.40 \\
\hline
\end{tabular}

a BET specific surface area. ${ }^{\mathrm{b}}$ Total pore volume. ${ }^{\mathrm{c}}$ Pore size calculated from BET. ${ }^{\mathrm{d}} \mathrm{Cu}$ loading of samples.

$0.23 \mathrm{~cm}^{3} \cdot \mathrm{g}^{-1}$ and hierarchically pores of $3.8,11.2,31.5 \mathrm{~nm}$ in size. Moreover, slight difference in $\mathrm{Cu}$ loadings can be obtained in the samples carbonized at different temperatures (Table 1), but they were mainly stay in the range of $50 \pm 2 \mathrm{wt} \%$. As for the samples pyrolyzed at low temperature, this type of difference mainly due to the undecomposed frameworks, i.e., D-HKUST-1-450 (49.77 wt\%). As for the high-temperature carbonization samples, the decrease of $\mathrm{Cu}$ loading might be caused by the undissolved $\mathrm{Cu}$ particle during ICP test.

The evolution of the structure of copper species after carbonization in Ar, activation in $\mathrm{H}_{2}$ and oxidation in air was recorded by XRD (Fig. 5). Two main species related to copper, i.e., metallic $\mathrm{Cu}$ and $\mathrm{Cu}_{2} \mathrm{O}$, can be detected in carbonized samples (Fig. 5(a)), no matter the reduction temperature is. Considering the fact that $\mathrm{Cu}_{2} \mathrm{O}$ phase was existed in the as-prepared HKUST-1 as it was exhibited in Fig. 2(d), thus it is difficult to tell the formation of $\mathrm{Cu}_{2} \mathrm{O}$, but the phase of metallic $\mathrm{Cu}$ verifies the fact that part of $\mathrm{Cu}$ ions was successfully reduced. It agrees with theoretical prediction that $\mathrm{Cu}^{2+}$ species were supposed to be reduced to metallic $\mathrm{Cu}$ as the reduction protentional of $\mathrm{Cu}^{2+}$ is $0.34 \mathrm{~V}$, which is much higher that -0.27 (the reduction potential of MOF pyrolysis) [35]. As for the phase of $\mathrm{Cu}_{2} \mathrm{O}$ formation, an additional experiment was designed by exposing carbonized HKUST-1 (e.g., D-HKUST-1-600) to air for different time, with XRD results are included in Fig. 5(b). It is found that only metallic $\mathrm{Cu}$ was formed after carbonized at $600{ }^{\circ} \mathrm{C}$, and it gradually transformed to $\mathrm{Cu}_{2} \mathrm{O}$ after exposing to air from 0.5 to $1.5 \mathrm{~h}$.

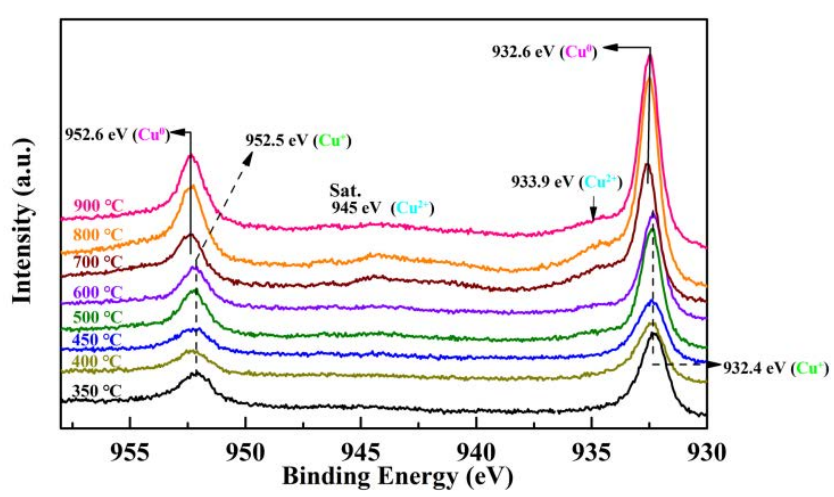

Fig. 6. High-resolution XPS spectra for $\mathrm{Cu} 2 p$ of the D-HKUST-1-X.

Since $\mathrm{CuO}$ is more thermodynamics stable than $\mathrm{Cu}_{2} \mathrm{O}$ under air, thus the observation of $\mathrm{Cu}_{2} \mathrm{O}$, instead of $\mathrm{CuO}$, formation might mean the strong interaction existed between $\mathrm{Cu}$ and $\mathrm{C}$ support in the carbonized samples. This result also indicates that the $\mathrm{Cu}_{2} \mathrm{O}$ phase in Fig. 5(a) are were mainly from the oxidation of metallic $\mathrm{Cu}$ as the XRD characterization was not in situ but performed under air after HKUST-1 carbonization. As a result, the formation of $\mathrm{Cu}_{2} \mathrm{O}$ can be observed due to the strong metal support interaction (SMSI). Anyway, the oxidized copper can be transformed to metallic copper after activation at $350^{\circ} \mathrm{C}$ for $2 \mathrm{~h}$ under $\mathrm{H}_{2}$.

The chemical state of copper in the carbonized samples was evaluated by XPS technique (Fig. 6). All samples displayed similar Cu $2 p$ XPS spectra, where the two main peaks appear in the region around 933 and $953 \mathrm{eV}$, corresponding to the $2 p_{3 / 2}$ and $2 p_{1 / 2}$ peaks of $\mathrm{Cu}^{0} / \mathrm{Cu}^{+}$species, respectively. With the increase of carbonization temperature, metallic $\mathrm{Cu}$ became the main phase on the surface of $\mathrm{Cu}$ particles with a small amount of $\mathrm{Cu}^{2+}$, which shows a weak peak around $934 \mathrm{eV}$. Moreover, existence of $\mathrm{Cu}^{2+}$ species was also further confirmed by the shake-up satellite peaks near $945 \mathrm{eV}$ [47]. It was found that the content of copper oxides (i.e., $\mathrm{Cu}_{2} \mathrm{O}$ and $\mathrm{CuO}$ ) gradually increase, due to the oxidation of $\mathrm{Cu}$ particles. It highly agrees with the results obtained by XRD. Since the test was not performed in-situ after carbonization, thus, except $\mathrm{Cu}$ and $\mathrm{C}$, the presence
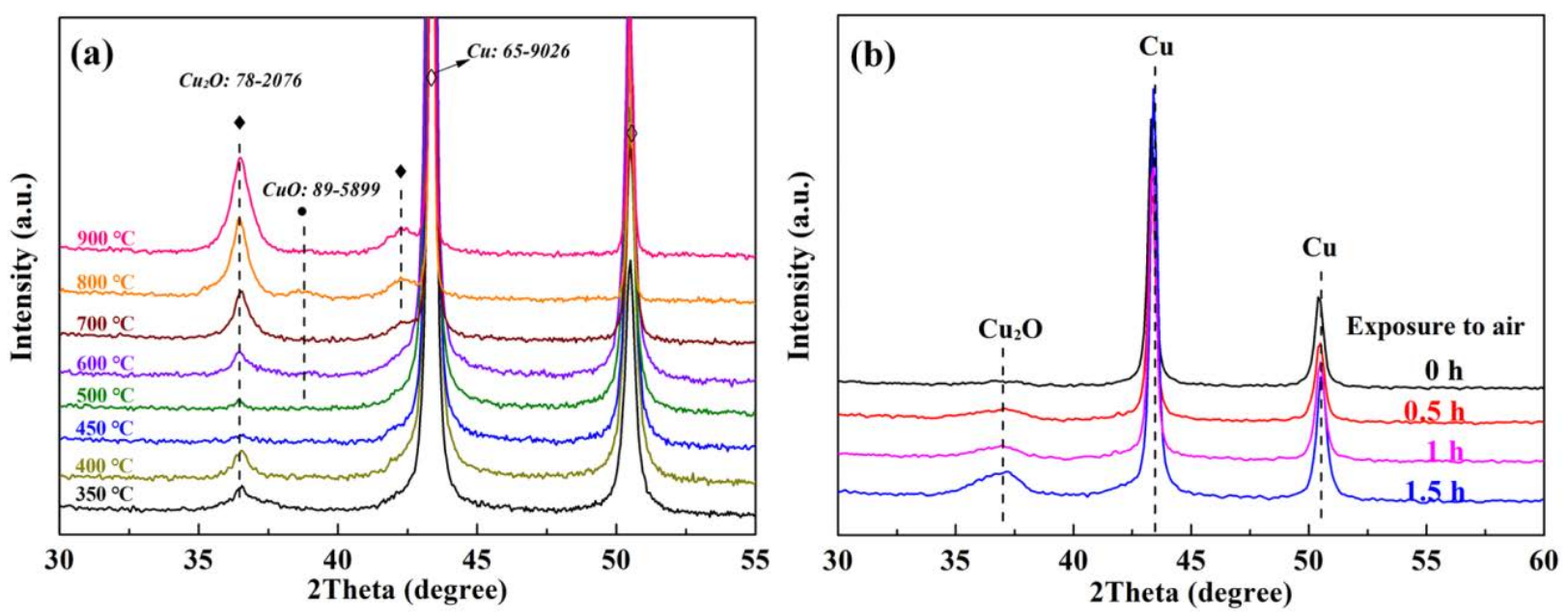

Fig. 5. XRD patterns of D-HKUST-1-X (a) and a reduced D-HKUST-1-600 after exposing to air for different times (b). 
of 0 can also be observed in the full spectra of D-HKUST-1-X (Fig. S7).

\subsection{Catalytic performance of D-HKUST-1-X}

Here, a temperature programmed reaction was employed for the evaluation of the catalytic activity, selectivity to butenes and summarized in Fig. 7(a), (b). In addition, isothermal reaction was further performed on the samples for the study of catalytic stability, with results presented in Fig. 7(c).

According to Fig. 7(a), the carbonization temperature has a great effect on the catalytic activity of carbon supported copper. Specifically, after carbonization at $350{ }^{\circ} \mathrm{C}$, the catalyst has very low catalytic activity, with only $\sim 75 \%$ butadiene conversion at temperature as high as $120^{\circ} \mathrm{C}$. This might be due to the formed $\mathrm{Cu}$ nanoparticles are mainly in the formed hierarchi-
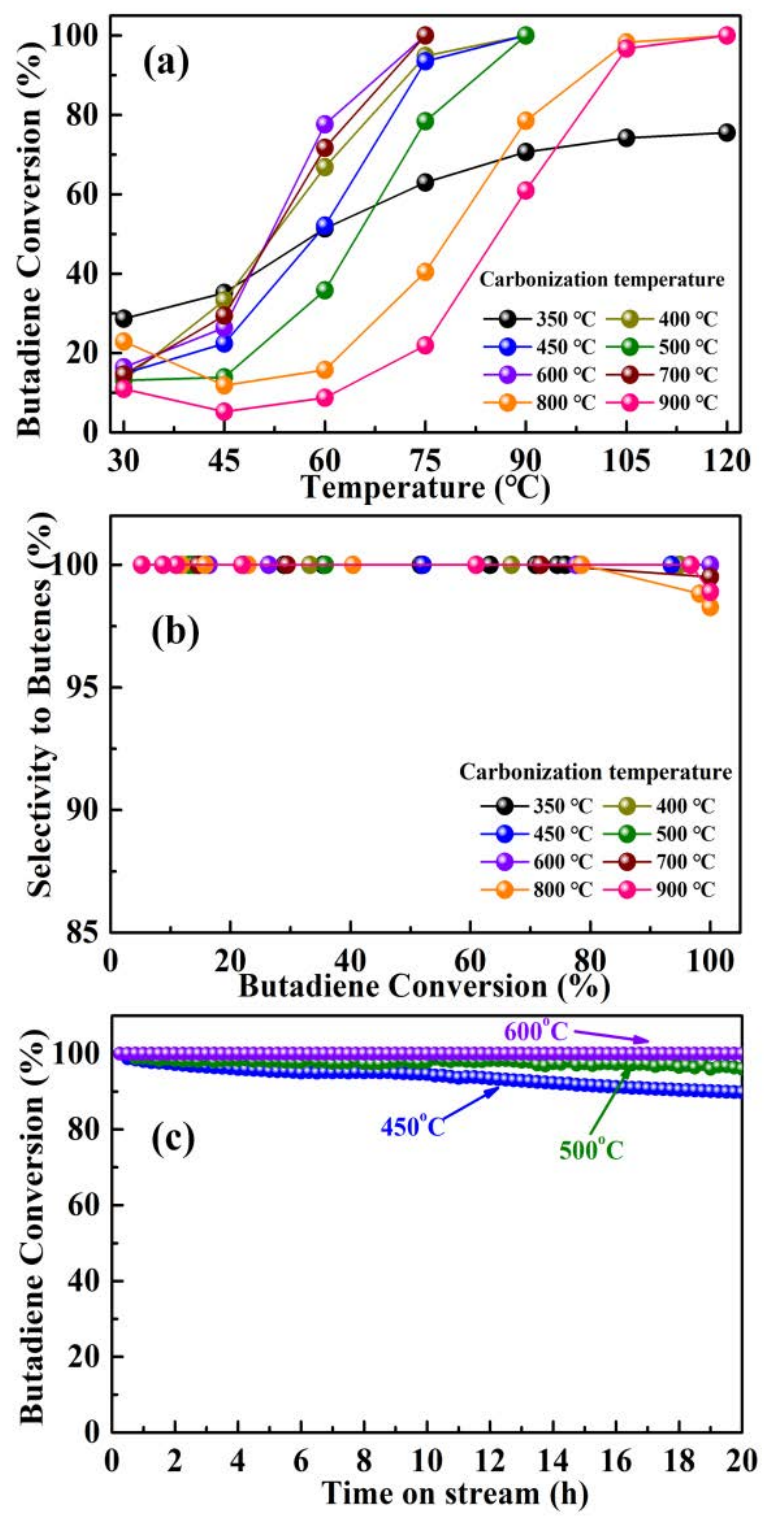

Fig. 7. Catalytic performance of D-HKUST-1-X. (a) Butadiene conversion as a function of temperature; (b) Selectivity to butenes as a function of butadiene conversion; (c) Evolution of the butadiene conversion with time on stream at $T_{100 \%}$ for D-HKUST-1- $X(X=450,500,600)$. cally porous carbon support (Fig. 2(a)), and it resulted in a very low exposed $\mathrm{Cu}$ surface for catalytic reaction. Moreover, the undecomposed organic fragments on the surface of HKUST-1 may also cause that the reactants can only access to the surface of catalyst. With the increase of carbonization temperature to 450 and $600^{\circ} \mathrm{C}$, the catalytic activity increases sharply, with the full butadiene conversion $\left(T_{100 \%}\right)$ decreases 90 to $75^{\circ} \mathrm{C}$, respectively. Considering the fact that the supported $\mathrm{Cu}$ has similar average particle size $(\sim 50 \mathrm{~nm})$ in the sample carbonized at 450 and $600{ }^{\circ} \mathrm{C}$ (Fig 2), however, the intensity of $\mathrm{C}=\mathrm{C}, \mathrm{C}-\mathrm{O}, \mathrm{C}-\mathrm{H}$ peaks related to the uncarbonized organic fragments in FTIR (Fig. S6) has a great decrease when carbonization temperature increases from 350 to $600^{\circ} \mathrm{C}$, it means that this type of increase in catalytic activity mainly due to the accelerated carbonization at high temperature remove the organic fragments and increase the exposure of catalytic active site. However, the catalytic activity decreases gradually with carbonization temperature keeps increase, with $T_{100 \%}$ decreases to $\sim 120{ }^{\circ} \mathrm{C}$ when HKUST-1 carbonized at $900{ }^{\circ} \mathrm{C}$. Since the organic framework was fully carbonized, verified by FTIR (Fig. S6), the decreases of catalytic activity supposed to be mainly due to the $\mathrm{Cu}$ particle sized increase, i.e., $\sim 52$ and $\sim 290 \mathrm{~nm}$ for the sample carbonized at 600 and $900{ }^{\circ} \mathrm{C}$, respectively. Comparing with previous study, which show $\mathrm{T}_{100 \%}$ at $165{ }^{\circ} \mathrm{C}$ for $\mathrm{Au}$-based $/ \mathrm{Al}_{2} \mathrm{O}_{3}$ [10], $T_{100 \%}$ at $80{ }^{\circ} \mathrm{C}$ for the catalyst carbonized from Co-BTC [48], the copper-based catalysts synthesized through the carbonization of HKUST-1 show high catalytic activity.

As for the catalytic selectivity, it can be expressed as either selectivity to butenes or alkanes (butane + propane) formation as a mixture of butadiene and propene was employed for catalytic reaction, and the formed butene and propene may be further hydrogenated to butane and propane, respectively. Thus, here, the relationship between selectivity to butenes and butadiene conversion was selected and drawn for the evaluation of catalytic selectivity in Fig. 7(b). It can be seen that all samples have very high selectivity to butenes (> 98\%). Specifically, for the samples, which were carbonized at temperature lower than $700{ }^{\circ} \mathrm{C}, 100 \%$ selectivity to butenes can be observed at even full butadiene conversion. Reviewing the research of previous study [49], the supported noble bimetallic catalysts, such as $\mathrm{Au}-\mathrm{Pd}$ catalysts prepared through deposition of colloids stabilized by tetrakis phosphonium chloride (THPC) on $\mathrm{Al}_{2} \mathrm{O}_{3}$ support, just shows $95.7 \%$ selectivity to butenes with the full butadiene conversion $\left(T_{100 \%}\right)$ of $75^{\circ} \mathrm{C}$. In this work, the selectivity to butene shows slight decrease to $99.5 \%, 98.3 \%$ and $98.9 \%$ for the sample carbonized at 700,800 and $900{ }^{\circ} \mathrm{C}$, respectively. Here, D-HKUST-1-900 (as shown in Fig. S8, i.e., Raman spectra, its relative $I_{\mathrm{G}} / I_{\mathrm{D}}$ ratio as high as 0.97 ) with good selectivity can be attributed to highly graphitized carbon species, which can conduce to the potentiation of electron mobility and stabilization of the reactive intermediates in catalysis process [50].

Based on the catalytic activity and selectivity to butenes (Fig. 7(a), (b)), three samples, which are carbonized at 450, 500 and $600{ }^{\circ} \mathrm{C}$, respectively, are selected for the further comparison of catalytic stability as these samples show very high performance in both high catalytic activity $\left(T_{100 \%} 75-90{ }^{\circ} \mathrm{C}\right)$ and selectivity to butenes $\left(100 \%\right.$ butadiene conversion at $\left.T_{100 \%}\right)$. 


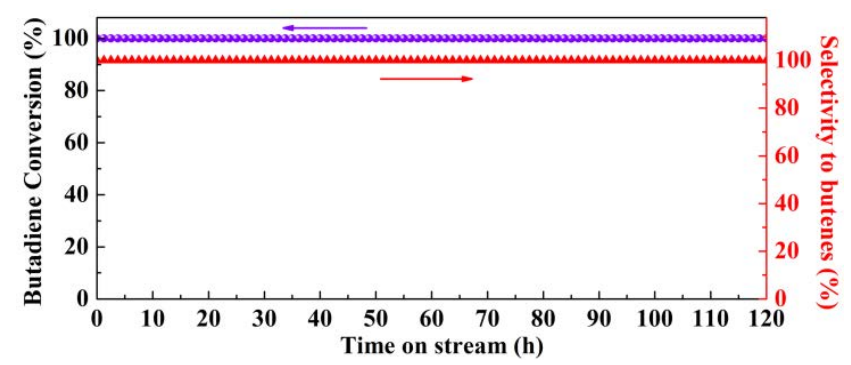

Fig. 8. Evolution of the butadiene conversion with time on stream at 75 ${ }^{\circ} \mathrm{C}$ for D-HKUST-1- 600 for $120 \mathrm{~h}$.

The catalytic stability tests of these samples were carried out under a constant temperature, at which the conversion rate of 1,3-butadiene to butenes just reached $100 \%$, obtained from catalytic activity test (Fig. 7 (c)), i.e., $90,90,75^{\circ} \mathrm{C}$ for the sample carbonized at 450,500 and $600{ }^{\circ} \mathrm{C}$, respectively, resulting in a similar initial butadiene conversion (100\%). In Fig. 7(c), the stability of the catalysts increases with the increase of carbonization temperature. For example, at the lowest carbonization temperature (i.e., $450{ }^{\circ} \mathrm{C}$ ), the initial butadiene conversion $(100 \%)$ decreases gradually to $\sim 90 \%$ after $20 \mathrm{~h}$ of catalytic reaction. While, as for the sample carbonized at $500{ }^{\circ} \mathrm{C}$, only $\sim 3 \%$ butadiene conversion decrease can be observed. Moreover, with the carbonization temperature increase to $600^{\circ} \mathrm{C}$, the butadiene conversion kept as $100 \%$ conversion after $20 \mathrm{~h}$ of reaction. Comprised with previous study focused on the catalytic stability of supported copper, for instance, $\mathrm{Pt}_{0.1} \mathrm{Cu}_{14} / \mathrm{Al}_{2} \mathrm{O}_{3}$ catalyst at the single- atom limit prepared by Lucci et al. [21] exhibits $98 \%$ selectivity to butenes and $\sim 5 \%$ decrease of butadiene conversion from the original $100 \%$ after $20 \mathrm{~h}$ of reaction. Another Cu-based catalyst produced by Wang et al. [8], i.e., 0.88 $\mathrm{wt} \% \mathrm{Cu} / \mathrm{TiO}_{2}$ catalyst shows rather low catalytic stability, with butadiene conversion decreased rather rapid from $\sim 100 \%$ directly to $\sim 10 \%$ in the first $2 \mathrm{~h}$ reaction, the carbon supported $\mathrm{Cu}$ catalysts synthesized by HKUST- 1 carbonization show rather high stability.

To verify the high catalytic stability of the catalysts obtained by HKUST- 1 carbonization, the sample carbonized at $600{ }^{\circ} \mathrm{C}$ was further tested at $75{ }^{\circ} \mathrm{C}$ (butadiene conversion just reached $100 \%$ ) as long as $120 \mathrm{~h}$ (Fig. 8), and it was supersized to found that the catalyst was very stable, with no observation of the decrease of butadiene conversion. It also shows that the sample carbonized at $600{ }^{\circ} \mathrm{C}$ has great potential for industrial application due to its high stability, high selectivity to butenes $(100 \%$ at $\left.T_{100 \%}\right)$ and a moderate catalytic activity $\left(T_{100 \%} \sim 75^{\circ} \mathrm{C}\right)$. Besides, as shown in Fig. S9, SEM images of D-HKUST-1-600 after $120 \mathrm{~h}$ of reaction are almost identical to those of the as-prepared catalyst. Meanwhile, Cu NPs are still uniformly embedded in the carbon species with retention of their original size.

\section{Conclusions}

In this work, hierarchically porous carbon supported high-density and high-dispersion metallic $\mathrm{Cu}$ nanoparticles catalysts were obtained by the carbonization of HKUST-1
(Cu-MOF). After catalytic performance evaluation on samples carbonized at different temperatures, it was found that the catalytic performance is obviously influenced by the particle size of $\mathrm{Cu}$ and the porous properties, which could be suitably tuned by carbonization temperature. Particularly, the derivative of HKUST-1 carbonized at $600{ }^{\circ} \mathrm{C}$ (i.e., D-HKUST-1-600) with moderate metal size $(\approx 51.9 \mathrm{~nm})$, large porous volume $\left(0.23 \mathrm{~cm}^{3} \cdot \mathrm{g}^{-1}\right)$ and reasonable hierarchically porous properties, exhibits $100 \%$ butadiene conversion and $100 \%$ butenes selectivity at $75{ }^{\circ} \mathrm{C}$. In addition, this type of hierarchically porous carbon supported highly-dispersed $\mathrm{Cu}$ catalyst still exhibits a rather high catalytic stability, with $100 \%$ butadiene conversion and $100 \%$ selectivity to butenes, after the testing time as long as $120 \mathrm{~h}$. This study attests the fact that the potential application of hierarchically porous carbon supported non-noble metals catalysts derived from the carbonization of MOFs, especially in selective hydrogenation of unsaturated hydrocarbons reaction.

\section{References}

[1] R. M. Bullock, Angew. Chem. Int. Ed., 2007, 46, 7360-7363.

[2] T. Gong, Y. Huang, L. Qin, W. Zhang, J. Li, L. Hui, H. Feng, Appl. Surf. Sci., 2019, 495, 143495.

[3] F. Zhang, X. Huang, Pet. Sci. Technol., 2009, 27, 291-301.

[4] G. Zeng, M. Liu, K. Shi, C. Heng, L. Mao, Q. Wan, H. Huang, F. Deng, X. Zhang, Y. Wei, Appl. Surf. Sci., 2016, 390, 710-717.

[5] Y. Feng, L. Zhou, Q. Wan, S. Lin, H. Guo, Chem. Sci., 2018, 9, 5890-5896.

[6] B. Yang, X. Q. Gong, H. F. Wang, X. M. Cao, J. J. Rooney, P. Hu, J. Am. Chem. Soc., 2013, 135, 15244-15250.

[7] Z. Wang, G. Wang, C. Louis, L. Delannoy, J. Catal., 2017, 347, 185-196.

[8] Z. Wang, D. Brouri, S. Casale, L. Delannoy, C. Louis, J. Catal., 2016, 340, 95-106.

[9] J. Huang, T. Odoom-Wubah, X. Jing, D. Sun, Z. Gu, Q. Li, ChemCatChem, 2017, 9, 870-881.

[10] A. Hugon, L. Delannov, C. Louis, Gold Bull., 2008, 49, 127-138.

[11] B. Bridier, D. Karhánek, J. Pérez-Ramírez, N. López, ChemCatChem, 2012, 4, 1420-1427.

[12] J. P. Peter Albers, S. F Parker, Acta Bot. Croat., 2001, 173, 275-286.

[13] W.-J. Kim, S. H. Moon, Catal. Today, 2012, 185, 2-16.

[14] B. K. Furlong, J. W. Hightower, T. Y.-L. Chan, A. Sarkany, L. Guczi, Appl. Catal. A, 1994, 117, 41-51.

[15] S. K. Kim, J. H. Lee, I. Y. Ahn, W.-J. Kim, S. H. Moon, Appl. Catal. A, 2011, 401, 12-19.

[16] M. Heemeier, A. F. Carlsson, M. Naschitzki, M. Schmal, M. Baumer, H. J. Freand, Angew. Chem. Int. Ed., 2002, 41, 4073-4076.

[17] C. Liu, Y. Xu, S. Liao, D. Yu, Appl. Catal. A, 1998, 172, 23.

[18] N. Semagina, M. Grasemann, N. Xanthopoulos, A. Renken, L. Kiwi-Minsker, J. Catal., 2007, 251, 213-222.

[19] M. W. Tew, H. Emerich, J. A. van Bokhoven, J. Phys. Chem. C, 2011, 115, 8457-8465.

[20] D. Liu, H. Y. Chen, J. Y. Zhang, J. Y. Huang, Y. M. Li, Q. M. Peng, Appl. Surf. Sci., 2018, 456, 59-68.

[21] F. R. Lucci, J. Liu, M. D. Marcinkowski, M. Yang, L. F. Allard, M. Flytzani-Stephanopoulos, E. C. H. Sykes, Nat. Commun., 2015, 6, 8550.

[22] K. Yang, B. Yang, J. Phys. Chem. C, 2018, 122, 10883-10891.

[23] C. Q. Lv, J. H. Liu, Y. Gu, G. C. Wang, Appl. Surf. Sci., 2019, 466, 


\section{Graphical Abstract}

Chin. J. Catal., 2020, 41: 1081-1090 doi: 10.1016/S1872-2067(20)63570-7

Enhanced stability of highly-dispersed copper catalyst supported by hierarchically porous carbon for long term selective hydrogenation

Nian Hu, Xiao-Yun Li, Si-Ming Liu, Zhao Wang *, Xiao-Ke He, Yue-Xin Hou, Yu-Xiang Wang, Zhao Deng, Li-Hua Chen *, Bao-Lian Su * Wuhan University of Technology, China; University of Namur, Belgium; University of Cambridge, UK

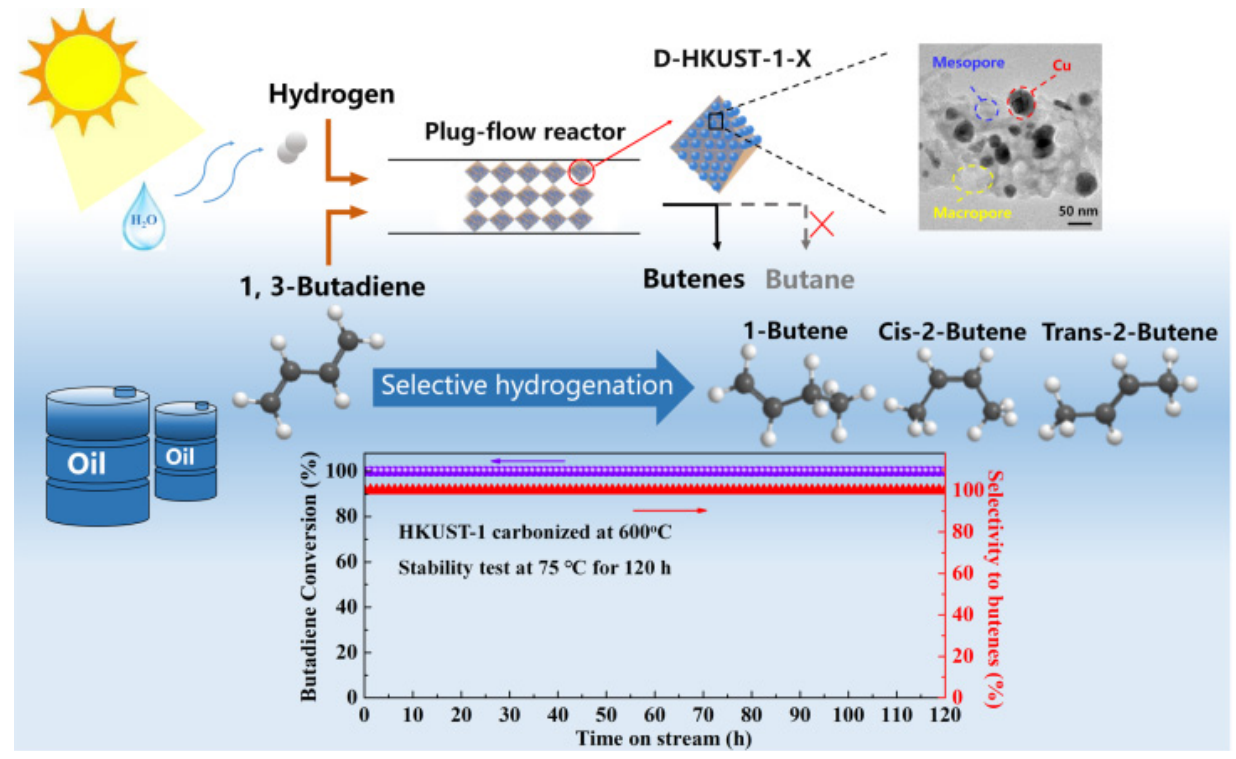

Enhanced stability of highly-dispersed copper catalyst supported by hierarchically porous carbon can be obtained by simply MOF carbonization for selective butadiene hydrogenation.

946-955.

[24] F. Studt, F. Abild-Pedersen, T. Bligaard, R. Z. Sorensen, C. H. Christensen, J. K. Norskov, Science, 2008, 320, 1320-1322.

[25] A. S. Hall, A. Kondo, K. Maeda, T. E. Mallouk, J. Am. Chem. Soc., 2013, 135, 16276-16279.

[26] H. Liu, S. Zhang, Y. Liu, Z. Yang, X. Feng, X. Lu, F. Huo, Small, 2015, 11, 3130-3134.

[27] T. Shu, L. Zhao, S. Li, X. Y. Chen, C. von Essen, K. Rissanen, D. Enders, Angew. Chem. Int. Ed., 2018, 57, 10985-10988.

[28] J. T. Wehrli, D. J. Thomas, M. S. Wainwright, D. L. Trimm, Appl. Catal. $A, \mathbf{1 9 9 1 , 7 0 , 2 5 3 - 2 6 2 .}$

[29] X. Zheng, G. Shen, C. Wang, Y. Li, D. Dunphy, T. Hasan, C. J. Brinker, B. L. Su, Nat. Commun., 2017, 8, 14921.

[30] P. Wu, L. H. Chen, S. S. Xiao, S. Yu, Z. Wang, Y. Li, B. L. Su, Nanoscale, 2018, 10, 11861-11868.

[31] L. G. Qiu, T. Xu, Z. Q. Li, W. Wang, Y. Wu, X. Jiang, X. Y. Tian, L. D. Zhang, Angew. Chem. Int. Ed., 2008, 47, 9487-9491.

[32] B. Liu, H. Shioyama, T. Akita, Q. Xu, J. Am. Chem. Soc., 2008, 130, 5390-5391.

[33] W. Bak, H. S. Kim, H. Chun, W. C. Yoo, Chem. Commun., 2015, 51, 7238-7241.

[34] T. Shen, H. Zhou, J. Xin, Q. Fan, Z. Yang, J. Wang, T. Mei, X. Wang, N. Wang, J. Li, Appl. Surf. Sci., 2019, 498, 143822.

[35] R. Das, P. Pachfule, R. Banerjee, P. Poddar, Nanoscale, 2012, 4, 591-599.

[36] L. J. Shen, G. J. Wang, X. X. Zheng, Y. N. Cao, Y. F. Guo, K. Lin, L. L. Jiang, Chin. J. Catal., 2017, 38, 1373-1381.
[37] Y. Qu, Z. Li, W. Chen, Y. Lin, T. Yuan, Z. Yang, C. Zhao, J. Wang, C. Zhao, X. Wang, F. Zhou, Z. Zhuang, Y. Wu, Y. Li, Nat. Catal., 2018, 1, 781-786.

[38] A. Han, W. Chen, S. Zhang, M. Zhang, Y. Han, J. Zhang, S. Ji, L. Zheng, Y. Wang, L. Gu, C. Chen, Q. Peng, D. Wang, Y. Li, L. Zheng, Y. Wang, L. Gu, Adv. Mater., 2018, 30, e1706508.

[39] J. Su, Y. Yang, G. Xia, J. Chen, P. Jiang, Q. Chen, Nat. Commun., 2017, 8, 14969.

[40] X. Li, B. Zhang, Y. Fang, W. Sun, Z. Qi, Y. Pei, S. Qi, P. Yuan, X. Luan, T. W. Goh, W. Huang, Chem. Eur. J., 2017, 23, 4266-4270.

[41] K. Chen, J. Ling, C. Wu, Angew. Chem. Int. Ed., 2019, DOI: 10.1002/anie.201913811

[42] C. Y. Chuah, K. Goh, T.-H. Bae, J. Phys. Chem. C, 2017, 121, 6748-6755.

[43] L. H. Wee, M. R. Lohe, N. Janssens, S. Kaskel, J. A. Martens, J. Mater. Chem., 2012, 22, 13742-13746.

[44] N. Al-Janabi, P. Hill, L. Torrente-Murciano, A. Garforth, P. Gorgojo, F. Siperstein, X. Fan, Chem. Eng. J., 2015, 281, 669-677.

[45] J. Zhang, B. An, Y. Hong, Y. Meng, X. Hu, C. Wang, J. Lin, W. Lin, Y. Wang, Mater. Chem. Front., 2017, 1, 2405-2409.

[46] N. C. Burtch, H. Jasuja, K. S. Walton, Chem. Rev., 2014, 114, 10575-10612.

[47] O. P. H. Vaughan, G. Kyriakou, N. Macleod, M. Tikhov, R. M. Lambert, J. Catal., 2005, 236, 401-404.

[48] Y. Jiang, G. Liu, S. Wu, X. Zhang, X. Dai, Q. Sheng, Y. Wang, H. Wang, Microporous Mesoporous Mater., 2019, 288, 109557.

[49] N. E. Kolli, L. Delannoy, C. Louis, J. Catal., 2013, 297, 79-92. 


\title{
超高稳定性的等级孔碳负载高分散铜基选择性加氢催化剂
}

\author{
胡 念 ${ }^{\mathrm{a}, \dagger}$, 李小云 ${ }^{\mathrm{b}, \dagger}$, 刘思明 ${ }^{\mathrm{a}}$, 王 朝 ${ }^{\mathrm{a},{ }^{*}}$, 何小可 ${ }^{\mathrm{a}}$, 侯月新 ${ }^{\mathrm{a}}$, 王宇翔 ${ }^{\mathrm{a}}$,

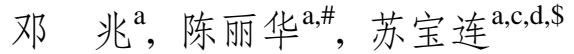 \\ a 武汉理工大学材料复合新技术国家重点实验室, 湖北武汉430070, 中国

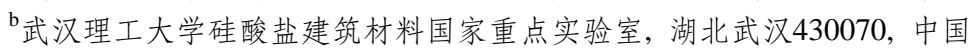 \\ c 那慕尔大学无机材料化学实验室, 比利时 \\ 剑桥大学克莱尔霍学院, 英国
}

\begin{abstract}
摘要: 负载型Pd, Pt, Au等贵金属催化剂由于具有较高活性而被广泛应用于选择性加氢催化领域, 但资源稀缺、价格昂贵等 问题严重制约了其在催化领域的长远发展. 目前大量研究结果表明, 非贵金属催化剂也具有较高的选择性催化加氢能力, 在已被报道的非贵金属加氢催化剂中, 铜基催化剂由于在选择性加氢反应中表现出较高加氢选择性和活性引起了人们的 广泛关注. 然而, 早期研究的负载型铜基催化剂普遍存在催化稳定性较低的问题, 所以提高铜基催化剂的使用寿命成为了 问题关键. 本文以铜基有机金属框架HKUST-1作为合成目标催化剂的前驱体, 首先探究了水热合成条件对HKUST-1合成 结构完整性及结晶度的影响, 再通过精确调控HKUST-1的原位碳化过程, 利用金属有机框架高温分解自还原行为, 成功制 备出了等级孔碳负载的高分散铜基催化剂, 并将所制备的催化剂应用于1,3-丁二烯选择性加氢反应中. 扫描电子显微镜、 高分辨透射电子显微镜、X射线衍射、氮气吸脱附、傅里叶红外吸收光谱、X射线光电子能谱等技术用来表征了碳化前后 催化剂载体结构的变化, 铜粒子尺寸、价态及其在载体中分布的变化. 文中也深入探究了以上因素对催化剂选择性催化加 氢性能的影响. 研究表明: $120^{\circ} \mathrm{C}$ 水热合成 $18 \mathrm{~h}$ 能获得尺寸在 $15 \mu \mathrm{m}$ 左右, 结晶度高且形貌规整的HKUST- 1 前驱体. 随后通 过合理地控制金属有机框架分解过程, 可实现对碳载体的等级孔结构和活性铜纳米粒子的分散程度的精确调控, 获得高效 等级孔载体结构和高分散铜位点的催化剂. 不仅如此, 通过一步碳化自还原HKUST-1制备的等级孔碳负载Cu的催化性能 表现出对碳化温度高度的关联性. 其催化活性随碳化处理温度的升高呈现先增强后减弱的趋势, 但所有获得的催化剂对 单烯烃都具有很高的选择性 $(>98 \%)$. 特别地, 本文发现在 $600{ }^{\circ} \mathrm{C}$ 碳化合成的催化剂在低温 $75^{\circ} \mathrm{C}$ 反应可实现对 $1,3-丁 二$ 二烯的 $100 \%$ 转化, 对丁烯的选择性为 $100 \%$. 同时, 该催化剂在恒温 $75^{\circ} \mathrm{C}$ 下持续反应 $120 \mathrm{~h}$ 以上, 其对丁二烯转化率和对丁烯选择 性依然保持 $100 \%$, 表现出了超高的催化稳定性和潜在的商用价值. 本文展示了通过简单地调控金属有机骨架的碳化过程 是获得具有优异选择性催化加氢性能的铜基催化剂的有效途径.
\end{abstract}

关键词: 等级孔结构; 催化剂; 碳载铜; 选择性加氢; 金属有机骨架

收稿日期: 2019-11-26. 接受日期: 2019-12-18. 出版日期: 2020-07-05.

*通讯联系人. 电话: 13628664510; 电子信箱: zhao.wang@whut.edu.cn

\#通讯联系人. 电话: 13628644340; 电子信箱: chenlihua@whut.edu.cn

通讯联系人. 电话: 13644968782; 电子信箱: bao-lian.su@unamur.be

†共同第一作者.

基金来源：教育部长江学者创新团队发展计划(IRT_15R52); 国家自然科学基金(21902122，21671155，U1663225，21805216);湖 北省技术创新专项重大项目(2018AAA012); 湖北省杰出青年基金(2018CFA054); 中国博士后科研基金(2019M652723); 中央高 校基本科研业务费资助(2019IVA116).

本文的电子版全文由Elsevier出版社在ScienceDirect上出版(http://www.sciencedirect.com/science/journal/18722067). 